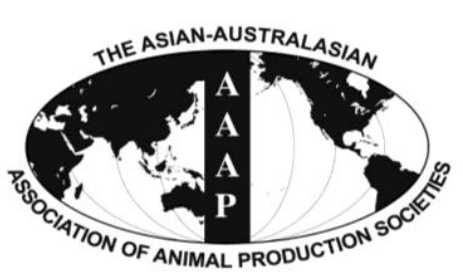

Open Access

Asian Australas. J. Anim. Sci.

Vol. 27, No. 12 : 1755-1762 December 2014

http://dx.doi.org/10.5713/ajas.2014.14255

www.ajas.info

pISSN 1011-2367 elSSN 1976-5517

\title{
Effects of Maize Source and Complex Enzymes on Performance and Nutrient Utilization of Broilers
}

\author{
Defu Tang, Shengyan Hao ${ }^{1}$, Guohua Liu ${ }^{2}$, Fang Nian, and Yingjun Ru* \\ College of Animal Science and Technology, Gansu Agricultural University, Lanzhou 730070, China
}

\begin{abstract}
The objective of this study was to investigate the effect of maize source and complex enzymes containing amylase, xylanase and protease on performance and nutrient utilization of broilers. The experiment was a $4 \times 3$ factorial design with diets containing four source maize samples (M1, M2, M3, and M4) and without or with two kinds of complex enzyme A (Axtra XAP) and B (Avizyme 1502). Nine hundred and sixty day old Arbor Acres broiler chicks were used in the trial (12 treatments with 8 replicate pens of 10 chicks). Birds fed M1 diet had better body weight gain (BWG) and lower feed/gain ratio compared with those fed M3 diet and M4 diet $(\mathrm{p}<0.05)$. Apparent ileal crude protein digestibility coefficient of M2 was higher than that of M3 ( $<<0.05)$. Apparent metabolisable energy (AME) and nitrogen corrected AME (AMEn) of M1 were significant higher than those of M4 ( $<<0.05)$. Supplementation of the basal diets with enzyme A or B improved the BWG by $8.6 \%(\mathrm{p}<0.05)$ and $4.1 \%(\mathrm{p}>0.05)$, respectively. The fresh feces output was significantly decreased by the addition of enzyme $B(p<0.05)$. Maize source affects the nutrients digestibility and performance of broilers, and a combination of amylase, xylanase and protease is effective in improving the growth profiles of broilers fed maizesoybean-rapeseed-cotton mixed diets. (Key Words: Broiler, Complex Enzyme, Maize, Growth Performance, Nutrient Digestibility)
\end{abstract}

\section{INTRODUCTION}

In a typical broiler diet formulation, maize can contribute about $65 \%$ of broiler metabolisable energy (ME) requirements (Baurhoo et al., 2011), which suggests that maize quality differences may lead to dramatic variance in chicks growth performance and feed costs per unit of production. The nitrogen corrected apparent metabolisable energy (AMEn) of maize for broilers may vary by more than $400 \mathrm{kcal} / \mathrm{kg}$ and was affected by genetics, agronomic conditions, proximate composition, pre- and postharvest processing variables, and the presence of anti-nutritional factors such as phytate, resistant starch, enzyme inhibitors and insoluble non-starch polysaccharides (Cowieson, 2005; Rutherfurd et al., 2007; Gehring et al., 2013).

It is evident that maize was not completely digested by

\footnotetext{
* Corresponding Author: Yingjun Ru. Tel: +86-931-7631225, Fax: +86-931-7632468, E-mail: yj.ru@ 163.com

${ }^{1}$ Gansu Academy Agricultural Sciences, Lanzhou 730070, China.

${ }^{2}$ Feed Research Institute, Chinese Academy of Agricultural Sciences, Beijing 100081, China.

Submitted Apr. 7, 2014; Revised May 29, 2014; Accepted Jun. 25, 2014
}

broilers in the small intestine and considerable amounts of starch and protein reached to the hindgut for fermentation with a relatively low energy yield (Noy and Sklan, 1995). Raw soybean, rapeseed and cotton meal contain antinutritive substances, the significant quantities of which are trypsin inhibitors and nonstarch polysaccharides (NSP) which reduce nutrient bioavailability by increasing digesta viscosity (Choct and Annison, 1990; Zanella et al., 1999; Malathi and Devegowda, 2001; Slominski, 2011).

Exogenous enzyme blends containing various combinations of amylase, protease, xylanase, glucanase, cellulase, mannanase, and pectinase have been assessed in broiler diets which contain high levels of soluble NSP and found to improve nutrients digestibility and bird growth performance (Yu and Chung, 2004; Meng and Slominski, 2005a; Meng et al., 2005b; Choct, 2006). Similar results were also reported in a maize soybean based diet, even if it contained a low level of NSP and digestible substrate (Bedford, 2000; Choct, 2006; Cowieson and Ravindran, 2008a,b; Zou et al., 2013). One area that has received relatively little attention in the literature, however, is the effect of maize source and complex enzyme on the broilers' 
growth performance and nutrients digestion, and the results were also inconsistent (O'neill et al., 2012; Zou et al., 2013). Therefore, more information is still required in this area of research. The objectives of the this study was to assess the effects of supplementation of a complex enzyme preparation on growth performance and nutrient utilization of broilers fed maize-soybean-rapeseed-cotton mixed diets (MSRC) containing four sourced maize.

\section{MATERIALS AND METHODS}

\section{Experimental design and diets}

The experiment was a $4 \times 3$ factorial design with four MSRC based on the four maize source samples and without or with the addition of complex enzyme $\mathrm{A}$ and $\mathrm{B}$, respectively. Four maize samples (M1, M2, M3, and M4) of JINSUI 1\# strain were collected from different regions of PR China in 2012. All samples had no mildew, no lumps and no insects. The samples were analyzed for the bulk density, content of dry matter (DM), total starch, amylose, amylopectin, crude protein (CP), gross energy, crude fat, crude ash, $\mathrm{Ca}, \mathrm{P}$, neutral detergent fiber, and acid detergent fiber before being used in the experimental diets. The results of chemical analysis of the four maize samples are shown in Table 1. Both enzyme A (Axtra XAP) containing 20,000 U xylanase, 2,000 U amylase and 40,000 U protease per gram and enzyme B (Avizyme 1502) containing $600 \mathrm{U}$ xylanase, $800 \mathrm{U}$ amylase and 8,000 U protease per gram, were sourced from Danisco Animal Nutrition (Marlborough, Wiltshire, UK), and the dose of addition in this study was 100 and $500 \mathrm{~g} / \mathrm{t}$, respectively.
Table 1. Physical and chemical characteristics of four maize samples (DM basis, \%)

\begin{tabular}{lcccc}
\hline Item & M1 & M2 & M3 & M4 \\
\hline Source & Tianshui & Dingxi & Lanzhou & zhangye \\
Rainfall & Sufficient & Medium & Medium & Drought \\
Bulk density (g/L) & 743.00 & 708.53 & 653.80 & 490.07 \\
DM & 90.29 & 87.59 & 88.63 & 88.77 \\
CP & 7.94 & 7.62 & 8.01 & 11.27 \\
Gross energy (MJ/kg) & 17.08 & 16.62 & 16.63 & 15.96 \\
EE & 3.19 & 4.37 & 3.76 & 3.88 \\
Crude ash & 1.11 & 1.03 & 1.03 & 1.12 \\
Ca & 0.01 & 0.01 & 0.02 & 0.02 \\
P & 0.24 & 0.26 & 0.31 & 0.26 \\
NDF & 8.42 & 9.48 & 7.52 & 9.25 \\
ADF & 2.24 & 3.32 & 1.75 & 3.17 \\
Total starch & 72.23 & 70.01 & 68.39 & 68.45 \\
Amylose & 19.78 & 16.72 & 17.78 & 17.80 \\
Amylopectine & 53.45 & 53.29 & 50.61 & 50.65 \\
\hline DM
\end{tabular}

DM, dry matter; CP, crude protein; EE, crude fat; NDF, neutral detergent fiber; $\mathrm{ADF}$, acid detergent fiber.

The four MSRC with isocaloric and isonitrogenous were formulated to meet the nutrient recommendation according to Feeding Standard of Chicken of the People's Republic of China (NY/T 33-2004). The ingredient composition and estimated nutrient content of the experimental basal diets are given in Table 2. Dietary protein was provided by the maize supplemented with commercial soybean meal, rapeseed meal, cotton meal and corn gluten meal. Synthetic methionine and lysine were added to the diets as needed to meet the industry standards.

Table 2. Composition and nutrient level of the basal diet (fed basis, \%)

\begin{tabular}{|c|c|c|c|c|c|c|}
\hline Ingredients & M1 & M2 & M3 & M4 & Nutrients & Nutrition level \\
\hline Maize & 62.00 & 62.00 & 62.00 & 62.00 & ME (MJ/kg) & 12.97 \\
\hline Vegetable oil & 1.25 & 1.25 & 1.25 & 1.25 & $\mathrm{CP}$ & 20.00 \\
\hline Soybean & 24.70 & 24.00 & 22.20 & 21.70 & $\mathrm{Ca}$ & 1.00 \\
\hline Cotton meal & 1.00 & 1.70 & 3.50 & 3.50 & $\mathrm{AP}$ & 0.45 \\
\hline Corn gluten meal & 3.00 & 3.00 & 3.00 & 3.00 & Met & 0.50 \\
\hline Rapeseed meal & 2.00 & 2.00 & 2.00 & 2.50 & Lys & 1.30 \\
\hline Limestone & 1.30 & 1.30 & 1.30 & 1.30 & Thr & 0.74 \\
\hline DCP & 1.80 & 1.80 & 1.80 & 1.80 & Trp & 0.20 \\
\hline Premix $^{1}$ & 1.00 & 1.00 & 1.00 & 1.00 & Arg & 1.15 \\
\hline Salt & 0.35 & 0.35 & 0.35 & 0.35 & Leu & 1.30 \\
\hline DL-Met & 0.25 & 0.25 & 0.25 & 0.25 & His & 0.38 \\
\hline L-Lys-HCL & 0.75 & 0.75 & 0.75 & 0.75 & & \\
\hline Choline Cl-50\% & 0.20 & 0.20 & 0.20 & 0.20 & & \\
\hline $\mathrm{TiO}_{2}$ & 0.40 & 0.40 & 0.40 & 0.40 & & \\
\hline Total & 100.0 & 100.0 & 100.0 & 100.0 & & \\
\hline
\end{tabular}

ME, metabolizable energy; CP, crude protein; AP, available phosphorus; Ca, calcium; Met, methionine; Lys, lysine; Thr, threonine; DCP, dicalcium phosphate; Trp, tryptophane ; Arg, arginine; Leu, leucine; His, histidine.

${ }^{1}$ Provided per kilogram of diet: vitamin A (as all-trans retinol), 12,000 IU; cholecalciferol, 3,500 IU; vitamin E (as d- $\alpha$-tocopherol), 44.7 IU; vitamin B 12 , $0.2 \mathrm{mg}$; biotin, $0.1 \mathrm{mg}$; niacin, $50 \mathrm{mg}$; vitamin $\mathrm{K}_{3}, 2 \mathrm{mg}$; pantothenic acid, $12 \mathrm{mg}$; folic acid, $2 \mathrm{mg}$; thiamine, $2 \mathrm{mg}$; riboflavin, $6 \mathrm{mg}$; pyridoxine hydrochloride, $5 \mathrm{mg}$; D-calciumpantothenate, $12 \mathrm{mg}$; Mn, $80 \mathrm{mg}$; Fe, $60 \mathrm{mg}$; Cu, $8 \mathrm{mg}$; I, 1mg; Co, $0.3 \mathrm{mg}$; and Mo, $1 \mathrm{mg}$. 
Exogenous enzyme A and B were added separately into the four basal diets. No growth promoters or other medications were added to the diets. Titanium dioxide $\left(\mathrm{TiO}_{2}, 0.4 \%\right)$ was added as an indigestible marker. Mash form diets were provided in this trial.

\section{Birds}

All experimental procedures were reviewed and approved by the Animal Care and Use Committee of Gansu Agricultural University (GAU). The feeding experiment was conducted in the cage pen house of the Animal Research Centre in GAU.

A total of 960 one-day-old Arbor Acres broiler chicks, obtained from a commercial hatchery, were individually weighed and randomly distributed by body weight to the 12 treatments with 8 replicate pens of 10 broilers (Male:female; 50:50). Room temperature was kept at $33^{\circ} \mathrm{C}$ to $35^{\circ} \mathrm{C}$ during the first week and gradually decreased to $24^{\circ} \mathrm{C}$ by the end of the third week. The birds were given free access to feed and water with constant fluorescent illumination. The trial lasted for $21 \mathrm{~d}$.

\section{Observations}

Growth performance: The broilers were weighed by pens at 0 and $21 \mathrm{~d}$ of age, feed consumption for each pen was recorded over 0 to $21 \mathrm{~d}$ period. Mortality was recorded daily. Any bird that died was weighed and the weight was used to adjust feed/gain ratio (F/G). The F/G was calculated by dividing total feed intake (FI) by weight of live plus dead birds.

Nutrients digestibility measurements: During 18 to $21 \mathrm{~d}$ of age, total excreta output were recorded daily and swabs of excreta were daily collected for the determination of apparent metabolisable energy (AME), AMEn, apparent CP and DM digestibility of total tract of birds. After collection, excreta were dried at $65^{\circ} \mathrm{C}$ and stored at $4{ }^{\circ} \mathrm{C}$ refrigerator. On d 21, all birds were killed by cervical dislocation and ileal digesta collected. The contents of the ileum were considered to be the part of the small intestine from the Meckel's diverticulum to approximately $1 \mathrm{~cm}$ proximal to the ileo-cecal junction. The ileal digesta was pooled within each cage, frozen, and stored at $-20^{\circ} \mathrm{C}$ prior to further process. All ileal samples were freeze-dried, ground by using a mortar and pestle prior to laboratory analysis. Diets and ileal digesta samples were analyzed for $\mathrm{DM}, \mathrm{TiO}_{2}$, gross energy and CP.

\section{Chemical analysis}

The DM and CP were determined according to AOAC (2005) procedures. Gross energy was determined using an adiabatic bomb calorimeter (IKA-2000, Staufen, Germany), standardised with benzoic acid. $\mathrm{TiO}_{2}$ was measured on a
UV spectrophotometer following the method of Short et al. (1996).

\section{Calculations}

The apparent fecal and ileal digestibility of nutrients (DM, energy and protein) were calculated by the following formula using the $\mathrm{TiO}_{2}$ marker ratio in the diet, excreta and digesta:

Digestibility of nutrients $=\frac{(\mathrm{NT} / \mathrm{Ti})_{\mathrm{d}}-(\mathrm{NT} / \mathrm{Ti})_{\mathrm{e}}}{(\mathrm{NT} / \mathrm{Ti})_{\mathrm{d}}} \times 100 \%$

Where:

$(\mathrm{NT} / \mathrm{Ti})_{\mathrm{d}}$ was the ratio of nutrient and $\mathrm{TiO}_{2}$ in diet.

$(\mathrm{NT} / \mathrm{Ti})_{\mathrm{e}}$ was the ratio of nutrient and $\mathrm{TiO}_{2}$ in digesta or excreta.

The AMEn was determined by correction for zero nitrogen retention by simple multiplication with $36.54 \mathrm{~kJ}$ per gram nitrogen retained in the body as described by Hill and Anderson (1958).

\section{Statistical analyses}

Data were analyzed by multivariate analysis of variance (ANOVA) of SPSS 16.0 for Windows (SPSS Inc., Chicago, IL, USA). The model included diet and enzyme as the main effects. Variable means for treatments showing significant differences in the ANOVA were separated by Tukey test. In all analyses, significance was declared at $\mathrm{p}<0.05$.

\section{RESULTS}

In this study, nine birds died not related to the experimental treatments, therefore, their data were excluded in the stats. The effect of dietary treatment on body weight gain (BWG), FI, and F/G is presented in Table 3. Birds fed M1 diet had better BWG (456.42 g/bird; $\mathrm{p}<0.05)$ and lower F/G (1.46; $p<0.05)$ compared with those fed M3 diet (394.59 g/bird; 1.65) and M4 diet (401.23 g/bird; 1.60). Supplementation of the basal diets with enzyme A or B improved the BWG by $8.6 \%(\mathrm{p}<0.05)$ and $4.1 \%(\mathrm{p}>0.05)$, respectively, and decreased the F/G by $5.0 \%(\mathrm{p}<0.05)$ and $1.9 \%$ ( $p>0.05$ ), respectively. The BWG and F/G of broilers were influenced by the interaction of maize sourcexenzyme, and birds fed M1 diet containing enzyme A had a significantly higher BWG than that of birds fed M3 or M4 diet without enzymes inclusion $(p<0.05)$, but the reverse case for the $F / G(p<0.05)$.

Apparent ileal $\mathrm{CP}$ digestibility coefficient of $\mathrm{M} 2$ $(71.72 \%)$ was higher $(p<0.05)$ than that of M3 $(67.44 \%$, Table 4). M4 had the lowest $(11.56 \pm 0.23 \mathrm{MJ} / \mathrm{kg} ; \mathrm{p}<0.05)$ ileal digestable energy (IDE) among maize source treatment groups. Diets containing enzyme A or B significantly 
Table 3. Effect of supplementing complex enzymes on performance of broilers (1 to $21 \mathrm{~d}$ )

\begin{tabular}{|c|c|c|c|c|c|}
\hline Maize & Enzyme & $\begin{array}{c}\text { No. of } \\
\text { replicates }\end{array}$ & $\begin{array}{c}\text { BWG } \\
\text { (g/bird) }\end{array}$ & $\begin{array}{c}\text { FI } \\
\text { (g/bird) }\end{array}$ & $\mathrm{F} / \mathrm{G}$ \\
\hline \multirow[t]{3}{*}{ M1 } & Without & 8 & $446.56^{\mathrm{ab}}$ & 662.58 & $1.48^{\mathrm{ab}}$ \\
\hline & Enzyme A & 8 & $473.44^{\mathrm{a}}$ & 679.33 & $1.43^{\mathrm{b}}$ \\
\hline & Enzyme B & 8 & $449.25^{\mathrm{ab}}$ & 669.57 & $1.47^{\mathrm{ab}}$ \\
\hline \multirow[t]{3}{*}{ M2 } & Without & 8 & $420.56^{\mathrm{ab}}$ & 673.03 & $1.60^{\mathrm{ab}}$ \\
\hline & Enzyme A & 8 & $445.20^{\mathrm{ab}}$ & 684.01 & $1.54^{\mathrm{ab}}$ \\
\hline & Enzyme B & 8 & $435.29^{\mathrm{ab}}$ & 692.26 & $1.59^{\mathrm{ab}}$ \\
\hline \multirow[t]{3}{*}{ M3 } & Without & 8 & $378.68^{b}$ & 642.17 & $1.69^{\mathrm{a}}$ \\
\hline & Enzyme A & 8 & $412.83^{\mathrm{ab}}$ & 646.72 & $1.59^{\mathrm{ab}}$ \\
\hline & Enzyme B & 8 & $392.25^{\mathrm{ab}}$ & 656.45 & $1.67^{\mathrm{a}}$ \\
\hline \multirow[t]{3}{*}{ M4 } & Without & 8 & $371.78^{b}$ & 624.71 & $1.68^{\mathrm{a}}$ \\
\hline & Enzyme A & 8 & $425.58^{\mathrm{ab}}$ & 658.82 & $1.55^{\mathrm{ab}}$ \\
\hline & Enzyme B & 8 & $406.32^{\mathrm{ab}}$ & 641.32 & $1.57^{\mathrm{ab}}$ \\
\hline \multicolumn{2}{|l|}{ SEM } & & 10.01 & 12.34 & 0.01 \\
\hline \multicolumn{2}{|l|}{ M1 } & 24 & $456.42^{\mathrm{a}}$ & 670.49 & $1.46^{\mathrm{b}}$ \\
\hline \multicolumn{2}{|l|}{ M2 } & 24 & $433.68^{\mathrm{ab}}$ & 683.10 & $1.57^{\mathrm{ab}}$ \\
\hline \multicolumn{2}{|l|}{ M3 } & 24 & $394.59^{b}$ & 648.45 & $1.65^{\mathrm{a}}$ \\
\hline \multicolumn{2}{|l|}{ M4 } & 24 & $401.23^{\mathrm{b}}$ & 641.61 & $1.60^{\mathrm{a}}$ \\
\hline \multicolumn{2}{|l|}{ SEM } & & 8.12 & 10.03 & 0.01 \\
\hline \multicolumn{2}{|l|}{ Without } & 32 & $404.40^{\mathrm{b}}$ & 650.62 & $1.61^{\mathrm{a}}$ \\
\hline \multicolumn{2}{|c|}{ Enzyme A } & 32 & $439.26^{\mathrm{a}}$ & 667.22 & $1.53^{\mathrm{b}}$ \\
\hline \multicolumn{2}{|c|}{ Enzyme B } & 32 & $420.78^{a b}$ & 664.90 & $1.58^{\mathrm{ab}}$ \\
\hline \multicolumn{2}{|l|}{ SEM } & & 7.96 & 8.34 & 0.01 \\
\hline \multicolumn{6}{|l|}{$\mathrm{p}$ value } \\
\hline \multicolumn{2}{|c|}{ Maize } & & 0.039 & 0.274 & 0.011 \\
\hline \multicolumn{2}{|c|}{ Enzyme } & & 0.048 & 0.792 & 0.009 \\
\hline \multicolumn{2}{|c|}{ Maizexenzyme } & & 0.009 & 0.144 & 0.008 \\
\hline
\end{tabular}

BW, body weight gain; FI, feed intake; F/G, feed:gain (g:g) was corrected for mortality; SEM, standard error of the mean.

Means in each column with no common character differ significantly $(\mathrm{p}<0.05)$.

improved the apparent $\mathrm{CP}$ digestibility coefficient and IDE compared to the no enzyme supplementation group $(\mathrm{p}<0.05)$. There was a significant $(\mathrm{p}<0.05)$ difference between maize source and exogenous enzymes on apparent $\mathrm{CP}$ digestibility coefficient and IDE. A huge variation of apparent ileal CP digestibility coefficient was exhibited between M2 diet supplemented with enzyme B (74.18\%) and M3 diet with no enzyme inclusion $(65.61 \%)(\mathrm{p}<0.05)$. M4 diet control was lower at IDE than that of M1 and M2 diets containing enzyme A or M2 diet containing enzyme B $(\mathrm{p}<0.05)$.

Total digestive tract $\mathrm{DM}$ digestibility and $\mathrm{N}$ retention were similar among broilers fed four MSRC ( $p>0.05)$ (Table 5). However, the enzymes supplementation improved the apparent total digestive tract DM digestibility and $\mathrm{N}$ retention of diets, but it did not reach a significant level $(\mathrm{p}=0.245 ; \mathrm{p}=0.058)$. The AME and AMEn of M1 was significantly higher $(p<0.05)$ than those of M4, and supplementation of the basal diets with enzyme A
Table 4. Effect of supplementing complex enzymes on apparent ileal nutrient digestibility of broilers at 21 days of age

\begin{tabular}{|c|c|c|c|c|c|}
\hline Maize & Enzyme & $\begin{array}{l}\text { No. of } \\
\text { replicates }\end{array}$ & $\begin{array}{c}\mathrm{DM} \\
\text { digestibility } \\
(\%)\end{array}$ & $\begin{array}{c}\mathrm{CP} \\
\text { digestibility } \\
(\%)\end{array}$ & $\begin{array}{c}\text { IDE } \\
(\mathrm{MJ} / \mathrm{kg})\end{array}$ \\
\hline \multirow[t]{3}{*}{$\overline{\mathrm{M} 1}$} & Without & 8 & 77.58 & $67.46^{\mathrm{bc}}$ & $12.01^{\mathrm{ab}}$ \\
\hline & Enzyme A & 8 & 78.89 & $70.25^{\mathrm{b}}$ & $12.34^{\mathrm{a}}$ \\
\hline & Enzyme B & 8 & 75.23 & $71.32^{\mathrm{ab}}$ & $12.09^{\mathrm{ab}}$ \\
\hline \multirow[t]{3}{*}{ M2 } & Without & 8 & 76.83 & $68.08^{b c}$ & $12.28^{\mathrm{ab}}$ \\
\hline & Enzyme A & 8 & 77.77 & $72.90^{\mathrm{ab}}$ & $12.34^{\mathrm{a}}$ \\
\hline & Enzyme B & 8 & 76.88 & $74.18^{\mathrm{a}}$ & $12.31^{\mathrm{a}}$ \\
\hline \multirow[t]{3}{*}{ M3 } & Without & 8 & 75.84 & $65.61^{\mathrm{c}}$ & $11.94^{\mathrm{ab}}$ \\
\hline & Enzyme A & 8 & 78.10 & $67.97^{\mathrm{bc}}$ & $12.23^{\mathrm{ab}}$ \\
\hline & Enzyme B & 8 & 77.23 & $68.76^{\mathrm{bc}}$ & $12.15^{\mathrm{ab}}$ \\
\hline \multirow[t]{3}{*}{ M4 } & Without & 8 & 74.72 & $68.83^{\mathrm{bc}}$ & $11.28^{\mathrm{b}}$ \\
\hline & Enzyme A & 8 & 77.74 & $70.68^{\mathrm{b}}$ & $11.87^{\mathrm{ab}}$ \\
\hline & Enzyme B & 8 & 78.15 & $72.15^{\mathrm{ab}}$ & $11.84^{\mathrm{ab}}$ \\
\hline \multicolumn{2}{|l|}{ SEM } & & 1.27 & 1.02 & 0.21 \\
\hline \multicolumn{2}{|l|}{ M1 } & 24 & 77.23 & $69.68^{\mathrm{ab}}$ & $12.15^{\mathrm{a}}$ \\
\hline \multicolumn{2}{|l|}{ M2 } & 24 & 77.16 & $71.72^{\mathrm{a}}$ & $12.31^{\mathrm{a}}$ \\
\hline \multicolumn{2}{|l|}{ M3 } & 24 & 77.06 & $67.44^{\mathrm{b}}$ & $12.11^{\mathrm{a}}$ \\
\hline \multicolumn{2}{|l|}{ M4 } & 24 & 76.87 & $70.55^{\mathrm{ab}}$ & $11.56^{\mathrm{b}}$ \\
\hline \multicolumn{2}{|l|}{ SEM } & & 1.04 & 0.85 & 0.18 \\
\hline \multicolumn{2}{|c|}{ Without } & 32 & 76.24 & $67.49^{\mathrm{b}}$ & $11.88^{\mathrm{b}}$ \\
\hline \multicolumn{2}{|c|}{ Enzyme A } & 32 & 78.13 & $70.45^{\mathrm{a}}$ & $12.20^{\mathrm{a}}$ \\
\hline \multicolumn{2}{|c|}{ Enzyme B } & 32 & 76.87 & $71.60^{\mathrm{a}}$ & $12.02^{\mathrm{a}}$ \\
\hline \multicolumn{2}{|l|}{ SEM } & & 1.00 & 0.81 & 0.17 \\
\hline \multicolumn{6}{|c|}{$\mathrm{p}$ value } \\
\hline \multicolumn{2}{|c|}{ Maize } & & 0.894 & 0.047 & 0.005 \\
\hline \multicolumn{2}{|c|}{ Enzyme } & & 0.596 & 0.041 & 0.026 \\
\hline \multicolumn{2}{|c|}{ Maizexenzyme } & & 0.504 & 0.047 & 0.029 \\
\hline
\end{tabular}

DM, dry matter; CP, crude protein; IDE, ileal digestable energy; SEM, standard error of the mean.

Means in each column with no common character differ significantly $(\mathrm{p}<0.05)$.

significantly improved the AME and AMEn by $0.33 \mathrm{MJ} / \mathrm{kg}$ $(\mathrm{p}<0.05)$ and by $0.46 \mathrm{MJ} / \mathrm{kg}(\mathrm{p}<0.05)$, respectively (Table 5). $\mathrm{N}$ retention, AME, and AMEn were influenced by the interaction of maize sourcexenzyme, and N retention of M4 diet containing enzyme $\mathrm{B}$ was higher than that of M3 diet with no enzyme inclusion $(\mathrm{p}<0.05)$. M1 diet supplemented with enzyme A or enzyme B had high AME and AMEn compared to the M3 and M4 diets containing no enzyme $(\mathrm{p}<0.05)$.

Table 6 shows that the water content of feces was not altered by maize source diets and complex enzymes (A and $B$ ), but the fresh feces output was significantly decreased by the addition of enzyme $B(p<0.05)$.

\section{DISSCUSSION}

The effect of maize source and complex enzymes on performance of broilers fed maize-soybean-rapeseed- 
Table 5. Effects of supplementing complex enzymes on total digestive tract nutrients utilization of broilers

\begin{tabular}{|c|c|c|c|c|c|c|}
\hline Maize & Enzyme & $\begin{array}{c}\text { No. of } \\
\text { replicates }\end{array}$ & $\mathrm{DM}(\%)$ & $\mathrm{N}$ retention $(\%)$ & AME (MJ/kg) & AMEn $(\mathrm{MJ} / \mathrm{kg})$ \\
\hline \multirow[t]{3}{*}{$\overline{\mathrm{M} 1}$} & Without & 8 & 79.23 & $71.43^{\mathrm{ab}}$ & $12.95^{\mathrm{ab}}$ & $12.74^{\mathrm{ab}}$ \\
\hline & Enzyme A & 8 & 80.12 & $73.12^{\mathrm{ab}}$ & $13.07^{\mathrm{a}}$ & $12.92^{\mathrm{a}}$ \\
\hline & Enzyme B & 8 & 79.59 & $73.34^{\mathrm{ab}}$ & $13.07^{\mathrm{a}}$ & $12.81^{\mathrm{a}}$ \\
\hline \multirow[t]{3}{*}{ M2 } & Without & 8 & 78.26 & $71.26^{\mathrm{ab}}$ & $12.61^{\mathrm{b}}$ & $12.35^{\mathrm{b}}$ \\
\hline & Enzyme A & 8 & 79.38 & $73.13^{\mathrm{ab}}$ & $12.83^{\mathrm{ab}}$ & $12.61^{\mathrm{ab}}$ \\
\hline & Enzyme B & 8 & 80.24 & $73.49^{\mathrm{ab}}$ & $12.89^{\mathrm{ab}}$ & $12.68^{\mathrm{ab}}$ \\
\hline \multirow[t]{3}{*}{ M3 } & Without & 8 & 77.68 & $69.98^{\mathrm{b}}$ & $12.62^{\mathrm{b}}$ & $12.43^{\mathrm{b}}$ \\
\hline & Enzyme A & 8 & 79.24 & $72.39^{\mathrm{ab}}$ & $12.97^{\mathrm{ab}}$ & $12.79^{\mathrm{ab}}$ \\
\hline & Enzyme B & 8 & 81.02 & $73.56^{\mathrm{ab}}$ & $12.75^{\mathrm{ab}}$ & $12.56^{\mathrm{ab}}$ \\
\hline \multirow[t]{3}{*}{ M4 } & Without & 8 & 76.35 & $71.21^{\mathrm{ab}}$ & $12.14^{\mathrm{c}}$ & $12.04^{\mathrm{c}}$ \\
\hline & Enzyme A & 8 & 79.21 & $73.43^{\mathrm{ab}}$ & $12.76^{\mathrm{ab}}$ & $12.58^{\mathrm{ab}}$ \\
\hline & Enzyme B & 8 & 77.36 & $75.45^{\mathrm{a}}$ & $12.73^{\mathrm{ab}}$ & $12.39^{\mathrm{ab}}$ \\
\hline SEM & & & 1.42 & 1.08 & 0.14 & 0.13 \\
\hline M1 & & 24 & 79.65 & 72.29 & $13.03^{\mathrm{a}}$ & $12.87^{\mathrm{a}}$ \\
\hline M2 & & 24 & 79.30 & 73.96 & $12.77^{\mathrm{ab}}$ & $12.55^{\mathrm{ab}}$ \\
\hline M3 & & 24 & 79.31 & 71.98 & $12.78^{\mathrm{ab}}$ & $12.59^{\mathrm{ab}}$ \\
\hline M4 & & 24 & 77.64 & 73.36 & $12.52^{\mathrm{b}}$ & $12.34^{\mathrm{b}}$ \\
\hline SEM & & & 1.38 & 1.01 & 0.12 & 0.11 \\
\hline Without & & 32 & 77.88 & 70.72 & $12.58^{\mathrm{b}}$ & $12.27^{\mathrm{b}}$ \\
\hline Enzyme A & & 32 & 79.49 & 73.52 & $12.91^{\mathrm{a}}$ & $12.73^{\mathrm{a}}$ \\
\hline Enzyme B & & 32 & 79.55 & 73.36 & $12.84^{\mathrm{ab}}$ & $12.61^{\mathrm{ab}}$ \\
\hline SEM & & & 1.29 & 0.95 & 0.11 & 0.10 \\
\hline \multicolumn{7}{|l|}{$\mathrm{p}$ value } \\
\hline Maize & & & 0.589 & 0.582 & 0.021 & 0.027 \\
\hline Enzyme & & & 0.245 & 0.058 & 0.044 & 0.045 \\
\hline Maizexenzyme & & & 0.895 & 0.049 & 0.040 & 0.042 \\
\hline
\end{tabular}

DM, dry matter; AME, apparent metabolisable energy; AMEn, nitrogen corrected apparent metabolisable energy; SEM, standard error of the mean. Means in each column with no common character differ significantly $(\mathrm{p}<0.05)$.

\section{cotton mixed diets}

The BWG and F/G of broilers fed MSRC were significantly different in the current study, which would suggest geographical origin of maize affects the growth performance of broilers. A similar finding was also reported by Brake et al. (2003) that there were significant BWG differences due to maize source at $21 \mathrm{~d}$ of age for live birds when birds fed maize soybean based diets. However, differing results were reported by O'neill et al. (2012) and Yegani and Korver (2013) that growth performance profiles of birds did not depend on the geographical source of maize. The lack of consistency in growth improvements among studies may be attributed to variations in the nutritive values, including $\mathrm{ME}, \mathrm{CP}$, and amino acid (Cowieson, 2005). In the current study, we observed that huge bulk density differences existed between M1 and M4, and Baidoo et al. (1991) investigated the positive relationships between AMEn and maize kernel density $(r=0.875)$. If this theory is correct, then M1 had higher AMEn than that of M4, consequently, a similar result was found in the present study. Therefore, we may use the bulk density parameter as the indicator of nutritional value of maize as it is in practical industry. Generally, gross energy parameter of grain is not meaningful in reflecting its nutritional value, but the gross energy value of M1 and M4 coincided with the changes of growth performance in this study. Therefore, gross energy may also as a good indicator for sample collection.

Supplementation of complex enzymes containing xylanase, amylase and protease to MSRC improved broiler's BWG and FCR in the current study, and the results were similar with the previous findings in broilers fed diets based on either so-called 'viscous' grains (wheat, barley, rye, triticale and oats) or low NSP content grain, such as maize (Bedford, 2000; Cowieson, 2005; Choct, 2006; Cowieson and Ravindran, 2008a,b). However, some early research suggested there wasn't any beneficial effect of enzyme complexes, including amylase and protease, on performance of broilers fed sorghum-soybean meal diet or maizesoybean diet (Mahagna et al., 1995; Douglas et al., 2000; Olukosi et al., 2007; West et al., 2007). Kocher et al. (2003) reported an exogenous complex enzyme product containing xylanase, amylase and protease had little effect on the performance of broiler chickens, and enzyme addition, in 
Table 6. Effect of supplementing complex enzymes on fresh fecal output and fecal water content of broilers

\begin{tabular}{|c|c|c|c|c|}
\hline Maize & Enzyme & $\begin{array}{l}\text { No. of } \\
\text { replicates }\end{array}$ & $\begin{array}{l}\text { Fresh feces } \\
\text { output }(\mathrm{g} / \mathrm{d})\end{array}$ & $\begin{array}{c}\text { Water } \\
\text { content }(\%)\end{array}$ \\
\hline \multirow[t]{3}{*}{ M1 } & Without & 8 & 35.43 & 63.61 \\
\hline & Enzyme A & 8 & 24.08 & 62.73 \\
\hline & Enzyme B & 8 & 28.26 & 66.45 \\
\hline \multirow[t]{3}{*}{ M2 } & Without & 8 & 34.86 & 69.07 \\
\hline & Enzyme A & 8 & 26.39 & 63.49 \\
\hline & Enzyme B & 8 & 25.29 & 67.12 \\
\hline \multirow[t]{3}{*}{ M3 } & Without & 8 & 33.0 & 64.91 \\
\hline & Enzyme A & 8 & 28.33 & 65.19 \\
\hline & Enzyme B & 8 & 27.12 & 63.25 \\
\hline \multirow[t]{3}{*}{ M4 } & Without & 8 & 26.82 & 63.54 \\
\hline & Enzyme A & 8 & 34.05 & 68.17 \\
\hline & Enzyme B & 8 & 24.13 & 65.21 \\
\hline SEM & & & 2.14 & 4.07 \\
\hline M1 & & 24 & 29.26 & 64.26 \\
\hline M2 & & 24 & 28.84 & 66.56 \\
\hline M3 & & 24 & 29.50 & 64.45 \\
\hline M4 & & 24 & 28.33 & 65.64 \\
\hline SEM & & & 2.01 & 3.89 \\
\hline Without & & 32 & $32.54^{\mathrm{a}}$ & 65.28 \\
\hline Enzyme & & 32 & $28.21^{\mathrm{ab}}$ & 64.90 \\
\hline Enzyme & & 32 & $25.21^{\mathrm{b}}$ & 65.51 \\
\hline SEM & & & 1.95 & 3.78 \\
\hline \multicolumn{5}{|l|}{$\mathrm{p}$ value } \\
\hline Maize & & & 0.738 & 0.841 \\
\hline Enzyn & & & 0.038 & 0.687 \\
\hline Maize & enzyme & & 0.327 & 0.754 \\
\hline
\end{tabular}

SEM, standard error of the mean.

Means in each column with no common character differ significantly $(\mathrm{p}<0.05)$

some cases, had a negative impact on performance variables (Brufau et al., 2006; Yegani and Korver, 2013). The explanation for the positive effects of enzyme addition in the current study could be that complex enzymes were better matched, so that the xylanase, amylase and protease were able to break down the cell wall matrix, especially the insoluble components, thereby facilitating the release of nutrients encapsulated in cell walls or incorporated into the cell wall itself, resulting in an easier access of digestive enzymes (Cowieson, 2005; Choct, 2006; Francesch and Geraert, 2009). In our study, the reasons why the BWG of birds fed M1 diet containing enzyme A was significantly higher than that of birds fed M3 or M4 diet without enzyme inclusion, and the reverse case for the F/G, were not clear, but it may have been due to an improvement of starch digestion of M1, which contained higher total starch than other maize samples.

The effect of maize source and complex enzymes on nutrient digestion and utilization of maize-soybean-

\section{rapeseed-cotton mixed diets by broilers}

The mode of action of enzymes in maize based diets has been linked to improved starch digestibility associated with augmentation of endogenous $\alpha$-amylase or improved digestion of resistant starches, improved access to cell contents via a reduction in cell wall integrity, modification of the intestinal microbial communities, improved protein solubility and digestibility and a reduction in the inimical effects of maize and/or soy-derived anti-nutritive factors (Cowieson and Ravindran, 2008b). Apparent ileal digestibility of DM, IDE, AME, and AMEn were significantly different for diets containing the four maize samples in the present study. This finding was in accordance with Cowieson (2005) who also reported the AME value of maize can vary by more than $2 \mathrm{MJ} / \mathrm{kg}$ from batch to batch making generic energy matrix values for maize inaccurate.

One way to improve the consistency of the nutritive value of maize is to add specific exogenous enzymes to ameliorate the adverse effects of anti-nutritional factors and to improve the digestibility of starch, oil and protein (Cowieson, 2005). In our study, apparent ileal digestibility of DM, CP and gross energy was improved by complex enzyme supplementation that also increased apparent total digestive tract digestibility of DM, CP, gross energy, and AMEn of the diet. Cowieson (2010) reported IDE was increased as a result of addition of xylanase+glucanase in the diet of 21-d-old broilers. Wyatt et al. (1999) reported that addition of an enzyme blend containing xylanase, amylase, and protease increased IDE of maize soybean diets in 28-d-old broiler chickens, which is in agreement with our observations. Rutherfurd et al. (2007) reported that addition of an enzyme mixture of xylanase, amylase, and glucanase in a corn-soy diet significantly increased ileal nitrogen digestibility in 29-d old broiler chickens. Oukosi et al. (2008) found that the combination of phytase with xylanase, amylase, and protease (XAP) in the negative control diet improved total tract retention of all nutrients as well as increased ME compared with the negative control diet, and similar results were also reported by Douglas et al. (2000) who found that ileal digestibility of energy at $21 \mathrm{~d}$ of age, AME and AMEn were improved when XAP are used in the maize soybean based diets for broilers. However, it is in contrast to the study of Olukosi et al. (2007) where there was no effect of a mixture of XAP on IDE in 21-d-old broiler chickens. The lack of effects of enzyme treatments on $\mathrm{CP}$ and gross energy digestibility in starter phase is in agreement with Mahagna et al. (1995), who did not observe any positive effects of the addition of exogenous amylase and protease on CP digestibility of sorghum-soy diets in 14d-old broiler chickens. Yegani and Korver (2013) also found the effects of enzyme products on IDE and digestibility of $\mathrm{CP}$ and amino acid were not consistent and 
varied depending on maize sources, enzyme products, and dietary phases. In current study, we also detected the apparent ileal CP digestibility coefficient, $\mathrm{N}$ retention, IDE, AME and AMEn could be influenced by the interaction of maize sourcexenzyme. M1 and M2 diets containing enzymes exhibited better $\mathrm{N}$ and energy utilization, which indicated there is correlative between maize quality and effect of enzyme supplementation, high quality maize is seen to be an advantage in improving nutritional value.

\section{The effect of maize source and complex enzymes on fresh fecal output of broilers fed maize-soybean- rapeseed-cotton mixed diets}

Animal manure output has been paid more attention due to its potential impact on the environment, which include effects on surface and ground water quality, soil quality, environment within housing systems, and emissions to the atmosphere. In US, annual manure output from farm animals is estimated to range from 133 (Burkholder et al., 2007 ) to 300 million metric tons (on a dry weight basis) per year. However, manure was applied on only 15.8 billion acres, which was about $5 \%$ of the total acres planted in 2006 (Scott and Kim, 2013). In a broiler's diet, high level protein (approximately 18\% to 23\%) is included to meet the requirement of growth, but only $60 \%$ to $80 \%$ of this is retained as animal protein, with the remaining $20 \%$ to $40 \%$ of the protein intake excreted in the manure. Substantial quantities of these mineral losses are recycled as landmass organic fertilizers are applied, but excess amounts tend to accumulate in the environment after repetition and time.

The use of appropriate enzyme blends has great potential for improving nutrient availabilities from feedstuffs and for reducing mineral emissions from animal production. Inclusion of phytase in diets increases $\mathrm{P}$ digestibility by approximately $20 \%$ to $50 \%$, resulting in marked decreases in $\mathrm{P}$ excretion (Woyengo and Nyachoti, 2011). In the present study, complex enzymes supplementation improved the DM digestibility and $\mathrm{N}$ retention. The possible explaination could be that enzymes hydrolyze storage non-starch polysaccharides, break down various anti-nutritional factors, release more nutrients and increase the availability of nutrients (Ferket et al., 2002).

In conclusion, this study indicated performance profiles could be influenced by maize source, and a combination of amylase, xylanase and protease is effective in improving the available energy and growth performance of broilers fed MSRC diet.

\section{ACKNOWLEDGMENTS}

The authors are grateful to Wang Yunxiang, Wang Guoxiu, and staff at the animal research center and College of Animal Science \& Technology of GAU (Lanzhou, PR,
China) for their effects of the this study. Funding for this research was provided by Danisco Animal Nutrition (Marlborough, Wiltshire, UK).

\section{REFERENCES}

AOAC International. 2005. Official Methods of Analysis. 18th ed. AOAC Int., Arlington, VA, USA.

Bedford, M. R. 2000. Exogenous enzymes in monogastric nutrition - their current value and future benefits. Anim. Feed Sci. Technol. 86:1-13.

Baurhoo, N., B. Baurhoo, and X. Zhao. 2011. Effects of exogenous enzymes in corn-based and Canadian pearl milletbased diets with reduced soybean meal on growth performance, intestinal nutrient digestibility, villus development, and selected microbial populations in broiler chickens. J. Anim. Sci. 89:4100-4108.

Brake, J., M. A. Faust, and J. Stein. 2003. Evaluation of transgenic event Bt11 hybrid corn in broiler chickens. Poult. Sci. 82:551559

Brufau, J., M. Francesch, and A. M. Pe'rez-Vendrell. 2006. The use of enzymes to improve cereal diets for animal feeding. J. Sci. Food Agric. 86:1705-1713.

Burkholder, J., B. Libra, P. Weyer, S. Heathcote, D. Kolpin, P. S. Thorne, and M. Wichman. 2007. Impacts of waste from concentrated animal feeding operations on water quality. Environ Health Perspect. 115:308-312.

Baidoo S. K., A. Shires, A. R. Robblee. 1991. Effect of kernel density on the apparent and true metabolizable energy value of corn for chickens. Poult. Sci. 70:2102-2107.

Choct, M. 2006. Enzymes for the feed industry: Past, present and future. World's Poult. Sci. J. 62:5-16.

Choct, M. and G. Annison. 1990. Anti-nutritive activity of wheat pentosans in broiler diets. Br. Poult. Sci. 31:811-821.

Cowieson, A. J. 2005. Factors that affect the nutritional value of maize for broilers. Anim. Feed Sci. Technol. 119:293-305.

Cowieson, A. J. 2010. Strategic selection of exogenous enzymes for corn/soy-based poultry diets. J. Poult. Sci. 47:1-7.

Cowieson, A. J. and V. Ravindran. 2008a. Sensitivity of broiler starters to three doses of an enzyme cocktail in maize-based diets. Br. Poult. Sci. 49:340-346.

Cowieson, A. J. and V. Ravindran. 2008b. Effect of exogenous enzymes in maize-based diets varying in nutrient density for young broilers: Growth performance and digestibility of energy, minerals and amino acids. Br. Poult. Sci. 49:37-44.

Douglas, M. W., C. M. Parsons, and M. R. Bedford. 2000. Effect of various soybean meal sources and Avizyme on chick growth performance and ileal digestible energy. J. Appl. Poult. Res. 9:74-80.

Francesch, M. and P. A. Geraert. 2009. Enzyme complex containing carbohydrases and phytase improves growth performance and bone mineralization of broilers fed reduced nutrient corn-soybean-based diets. Poult. Sci. 88:1915-1924.

Ferket, P. R., E. V. Heugten, T. A. T. G. Kempen, and R. Angel. 2002. Nutritional strategies to reduce environmental emission from nonruminants. J. Anim. Sci. 80:168-182.

Gehring, C. K., A. J. Cowieson, M. R. Bedford, and W. A. Dozier. 2013. Identifying variation in the nutritional value of corn 
based on chemical kernel characteristics. World's Poult. Sci. J. 69:299-311.

Hill, F. W. and D. L. Anderson. 1958. Comparison of metabolizable energy and productive energy determinations with growing chicks. J. Nutr. 64:587-603.

Kocher, A., M. Choct, G. Ross, J. Broz, and T. K. Chung. 2003. Effects of enzyme combinations on apparent metabolizable energy of corn-soybean meal-based diets in broilers. J. Appl. Poult. Res. 12:275-283.

Malathi, V. and G. Devegowda. 2001. In vitro evaluation of nonstarch polysaccharide digestibility of feed ingredients by enzymes. Poult. Sci. 80:302-305.

Mahagna, M., I. Nir, M. Larbier, and Z. Nitsan. 1995. Effect of age and exogenous amylase and protease on development of the digestive tract, pancreatic enzyme activities and digestibility of nutrients in young meat-type chicks. Reprod. Nutr. Dev. 35:201-212.

Meng, X. and B. A. Slominski. 2005a. Nutritive values of corn, soybean meal, canola meal, and peas for broiler chickens as affected by a multicarbohydrase preparation of cell wall degrading enzymes. Poult. Sci. 84:1242-1251.

Meng, X., B. A. Slominski, C. M. Nyachoti, L. D. Campbell, and W. Guenter. 2005b. Degradation of cell wall polysaccharides by combinations of carbohydrase enzymes and their effect on nutrient utilization and broiler chicken performance. Poult. Sci. 84:37-47.

Noy, Y. and D. Sklan. 1995. Digestion and absorption in the young chick. Poult. Sci. 74:366-373.

Olukosi, O. A., A. J. Cowieson, and O. Adeola. 2007. Age-related influence of a cocktail of xylanase, amylase, and protease or phytase individually or in combination in broilers. Poult. Sci. 86:77-86.

Oukosi, O. A., A. J. Cowieson, and O. Adeola. 2008. Influence of enzyme supplementation of maize-soyabean meal diets on carcase composition, whole-body nutrient accretion and total tract nutrient retention of broilers. Br. Poult. Sci. 49:436-445.

O'neill, H. V. M., N. Liu, J. P. Wang, A. Diallo, and S. Hill. 2012. Effect of xylanase on performance and apparent metabolisable energy in starter broilers fed diets containing one maize variety harvested in different regions of china. Asian Australas. J. Anim. Sci. 25:515-523.
Rutherfurd, S. M., T. K. Chung, and P. J. Moughan. 2007. The effect of a commercial enzyme preparation on apparent metabolizable energy, the true ileal amino acid digestibility, and endogenous ileal lysine losses in broiler chickens. Poult. Sci. 86:665-672.

Slominski, B. A. 2011. Recent advances in research on enzymes for poultry diets. Poult. Sci. 90:2013-2023.

Short. F. J., P. Gorton, J. Wiseman, and K. N. Boorman. 1996. Determination of titanium dioxide added as an inert marker in chicken digestibility studies. Anim. Feed Sci. Technol. 59:215221

Scott, D. and H. J. Kim. 2013. Technologies to reduce environmental impact of animal wastes associated with feeding for maximum productivity. Anim. Front. 3:42-47.

Wyatt, C. L., M. R. Bedford, and L. A. Waldron. 1999. Role of enzymes in reducing variability in nutritive value of maize using the ileal digestibility method. In: Proc. 10rd Ann. Aust. Poult. Sci. Symp. February 9-10, 1999; Sydney, Australia. pp.108-111.

West, M. L., A. Corzo, W. A. Dozier III, M. E. Blair, and M. T. Kidd. 2007. Assessment of dietary rovabio excel in practical United States broiler diets. J. Appl. Poult. Res. 16:313-321.

Woyengo, T. A. and C. M. Nyachoti. 2011. Review: Supplementation of a combination of phytase and carbohydrases to diets for poultry. Can. J. Anim. Sci. 91:177192

Yu, B. and T. K. Chung. 2004. Effects of multiple-enzyme mixtures on growth performance of broilers fed corn-soy meal diets. J. Appl. Poult. Res. 13:178-182.

Yegani, M. and D. R. Korver. 2013. Effects of corn source and exogenous enzymes on growth performance and nutrient digestibility in broiler chickens. Poult. Sci. 92:1208-1220.

Zanella, I., N. K. Sakomura, F. G. Silversides, and A. Fiqueirdo. 1999. Effect of enzyme supplementation of broiler diets based on corn and soybeans. Poult. Sci. 78:561-568.

Zou, J. L., P. Zheng, K. Y. Zhang, X. M. Ding, and S. P. Bai. 2013. Effects of exogenous enzymes and dietary energy on performance and digestive physiology of broilers. J. Anim. Sci. Biotechnol. 4:14. 